$$
\text { УДК. 347.77+347.77.028.4): (378+174):004.4 }
$$

$$
\text { https://doi.org/10.52058/2786-4952 -2021-3(3)-89-99 }
$$

Наконечний Андрій Йосифович доктор медичних наук, проректор 3 наукової роботи, професор кафедри дитячої хірургії, Львівський національний медичний університет імені Данила Галицького, вул. Пекарська, 69, м. Львів, 79000, тел.: (032) 275-76-32, e-mail: andrurol@gmail.com, https://orcid.org/0000$0003-1402-6642$

Ягело Світлана Петрівна кандидат філологічних наук, вчений секретар, старший викладач кафедри українознавства, Львівський національний медичний університет імені Данила Галицького, вул. Пекарська, 69, м. Львів, 79000, тел.: (032) 275-76-32, e-mail: syagelo@ukr.net, https://orcid.org/0000-0002-9990-1022

Вергун Андрій Романович доктор медичних наук, доцент, доцент кафедри сімейної медицини, старший інспектор наукового відділу, антиплагіатний експерт наукових, навчально-методичних праць та дисертаційних матеріалів, Львівський національний медичний університет імені Данила Галицького, вул. Пекарська, 69, м. Львів, 79000, тел.: (050) 747-33-40, e-mail: plagiamail@meta.ua, https://orcid.org/0000-0002-7521-3241

Корнієнко Марія Миколаївна кандидат медичних наук, асистент кафедри хірургічної стоматології та щелепно-лицевої хірургії, Львівський національний медичний університет імені Данила Галицького, вул. Пекарська, 69, м. Львів, 79000, тел.: (032) 275-76-32, e-mail: kornienkomariia@gmail.com, https://orcid.org/0000-0002-4345-6775

Вергун Оксана Михайлівна кандидат медичних наук, доцент кафедри терапії №1, медичної діагностики та гематології і трансфузіології ФПДО, лікартерапевт вищої категорії, Львівський національний медичний університет імені Данила Галицького, вул. Пекарська, 69, м. Львів, 79000, тел.: (050) 534-06-27, e-mail: plagiamail@ meta.ua, https://orcid.org/0000-0002-3990-8791

Макагонов Ігор Олександрович кандидат медичних наук, доцент кафедри сімейної медицини, Львівський національний медичний університет імені Данила Галицького, вул. Пекарська, 69, м. Львів, 79000, тел.: (050) 747-33-40, e-mail: e-mail: igormakagonov@gmail.com, https://orcid.org/0000-0003-2382-6262.

\title{
ВИБІР АНТИПЛАГІАТНИХ ПРОГРАМ ТА ЕКСПЕРТИЗА НАУКОВИХ ПРАЦЬ ЯК СКЛАДОВІ АКАДЕМІЧНОЇ ДОБРОЧЕСНОСТІ: ПОГЛЯДИ НА ПРОБЛЕМУ
}

Анотація. Проведено аналіз стану антиплагіатної еспертизи та сучасного програмного забезпечення для iі здійснення. Проаналізовано результати 
первинної перевірки наукових праць, відзначено проблемні аспекти та окреслено деякі перспективи і можливості щодо їх подолання в контексті ствердження та впровадження принципів академічної етики / академічної доброчесності, покращення наукової комунікації, вдосконалення системи освітньої і наукової діяльності.

Метою роботи було удосконалення заходів протидії порущенням академічної доброчесності та академічному плагіату на основі аналізу чинного законодавства та положень Львівського національного медичного університету імені Данила Галицького, досвіду антиплагіатної експертизи.

Вибір антиплагіатних програм здійснюється індивідуалізовано 3 урахуванням академічної етики, обсягу представленого на експертизу матеріалу, технічних аспектів оптимізації затрат часу та економічних факторів. За трьохрічний період (2018-2020 pр) у Львівському національному медичному університеті імені Данила Галицького здійснено 5535 перевірок на наявність академічного плагіату у наукових та навчально-методичних працях. Порушення академічної доброчесності до моменту затвердження до публікації констатовано у 611 роботах. Кожне антиплагіатне програмне забезпечення, незважаючи на подібність алгоритмів, має свої особливості, переваги, особливості пошукової індексації, практичного використання, інтерпретації результатів. За об'єктивність антиплагіатного експертного висновку відповідальність несе керівник відповідного структурного підрозділу. Відповідальна особа за результатами перевірки наукових робіт проводить облік, загальний аналіз їх рівня, оцінку ступеня унікальності тексту та валідності текстових співпадінь.

Ключові слова: університет, академічна доброчесність, антиплагіатна експертиза, програмне забезпечення, академічна етика.

Nakonechnyi Andrii Yosyfovych MD, PhD, Vice-Rector for Research, DSc, Professor of Pediatric Surgery Department, Danylo Halytskyi Lviv National Medical University, Pekarska St., 69, Lviv, 79000, tel.: (032) 275-76-32, e-mail: andrurol@gmail.com, https://orcid.org/0000-0003-1402-6642

Yagelo Svitlana Petrivna PhD, Scientific Secretary, Senior Lecturer of the Ukrainian Studies Department, Danylo Halytskyi Lviv National Medical University, Pekarska St., 69, Lviv, 79000, tel.: (032) 275-76-32, e-mail: syagelo@ukr.net, https://orcid.org/0000-0002-9990-1022

Vergun Andrii Romanovych MD, PhD, DSc, Associate Professor of the Family Medicine Department, Senior Inspector of the Scientific Department, Anti-plagiarism Expert of Scientific, Educational, Methodological Papers and Dissertation Materials, Danylo Halytskyi Lviv National Medical University, Pekarska St., 69, Lviv, 79000, tel.: (050) 747-33-40, e-mail: plagiamail@meta.ua, https://orcid.org/0000-0002-75213241, ResearcherID G-3998-2019 
Kornienko Maria Mykolaivna PhD, Assistant of the Department of Surgical Dentistry and Facial Surgery, Danylo Halytskyi Lviv National Medical University, Pekarska St., 69, Lviv, 79000, tel.: (032) 275-76-32, e-mail: kornienkomariia@gmail.com, https://orcid.org/0000-0002-4345-6775

Vergun Oksana Mykhailivna MD, PhD, Associate Professor of the Department of Therapy №1, Medical Diagnostics, Hematology and Transfusiology FPGE, Highest category physician, Danylo Halytskyi Lviv National Medical University, Pekarska St., 69, Lviv, 79000, tel.: (050) 534-06-27, e-mail: plagiamail@meta.ua, https://orcid.org/0000-0002-3990-8791

Makahonov Ihor Oleksandrovych $\mathrm{MD}, \mathrm{PhD}$, Associate Professor of the Family Medicine Department, Danylo Halytskyi Lviv National Medical University, Pekarska St., 69, Lviv, 79000, (050) 747-33-40, e-mail: igormakagonov@gmail.com, https://orcid.org/0000-0003-2382-6262

\section{ANTI-PLAGIARISM SOFTWARE AND EXPERTISE OF SCIENTIFIC WORKS AS A COMPONENT OF ACADEMIC INTEGRITY: VIEWS OF THE PROBLEM}

Abstract. The analysis of the state of anti-plagiarism examination and modern software for its is carried out. The results of the initial examination of scientific works are analyzed, problematic aspects are noted and some perspectives and possibilities for overcoming them in the context of approval and implementation of the academic integrity / academic ethics principles, improvement of scientific communication, of educational and scientific activity also are analyzed.

The aim of the work was to improve some measures to prevent of academic dishonesty and of academic plagiarism based on an analysis of the current laws ans / or regulations of the Danylo Halytskyi Lviv National Medical University and the experience of some new software introducing.

The experience of some adequate new software implementation are individually, taking into account the academic ethics, amount of material submitted for examination, technical aspects of time and cost optimization and economic factors. 5,535 inspections for the presence of academic plagiarism in scientific and educational-methodical works during the three-year period (2018-2020) in the Danylo Halytskyi Lviv National Medical University were carried out. Violations of academic integrity and dishonesty up to the moment of approval for publication in 611 works were stated. Each some antiplagiarism software with similar algorithms, has its own features, advantages, some nuances of search indexing, practical use, interpretation of results. The head of the relevant structural unit is the academic integrity expert and / or the anti-plagiarism examination expert. The responsible person keeps some general analysis of the scientific works based of the scientific / anti-plagiarism inspection results, assessment of the text uniqueness and textual / references validity. 

ethics.

Keywords: university, academic integrity, anti-plagiarism, software, academic

Постановка проблеми. Утвердження принципів академічної культури та доброчесності в навчальних закладах слугує передумовою розбудови сильної громадянської культури в суспільстві в цілому. Педагогічна i наукова комунікація у Львівському національному медичному університеті імені Данила Галицького посідає важливе місце у сучасному науковому та освітньому процесі $[1,10]$. Важливо, щоб ця комунікація відбувалась на засадах академічної доброчесності, що грунтуються на повазі до колег-науковців [10-13, 16-19]. Проте не завжди в академічному середовищі можна спостерігати дотримання вимог академічної етики $[14,16]$.

Аналіз останніх досліджень і публікацій. На жаль, у нашій країні, зокрема у закладах вищої освіти мають місце такі явища як фальсифікації, плагіат та академічний плагіат, що негативно впливають на різні сфери, включаючи освітню, наукову та дослідницьку діяльності [7-11]. Проте, саме становлення фундаментальних цінностей і вкорінення їх у поведінці молодої людини, попередження та своєчасне виявлення академічного плагіату закладає базу соціально відповідальної поведінки студентів і після закінчення вузу, а засвоєння та дотримання інститутів академічної культури та доброчесності (кодексу честі) позитивно впливає і визначає установки і цінності особистості поза межами навчального закладу. Загальноприйняті світовою спільнотою стандарти здійснення освітньої та наукової діяльності здобувачами вищої освіти i співробітниками університету [5-8, 12-18] й детермінують створення середовища нульової терпимості до порушень академічної доброчесності та етики академічних взаємовідносин [14].

Стійкою перепоною до впровадження принципів академічної доброчесності в Україні є «традиція» неякісних, несумісних із кращим світовим досвідом і вимогами практик академічного письма (недосконала структура наукової статті та анотації до неї, відсутність традиції належного рецензування, необхідність наукових публікацій для звіту, а не як презентації власного дослідження тощо) $[1,2,3]$. Це суттєво загальмовує оптимізацію та об'єктивізацію оцінки академічного письма в Україні як серед дослідників і викладачів, так і серед студентів. Відповідно до ст. 32 Закону України «Про вищу освіту» $[4,5,6]$ заклади вищої освіти (3ВО) зобов'язані вживати заходів, включаючи запровадження відповідних новітніх технологій, для запобігання та виявлення академічного плагіату в наукових роботах наукових, науково-педагогічних, педагогічних, інших працівників i здобувачів вищої освіти та притягнення їх (при наявності порушень академічної етики, зокрема фальсифікації результатів наукових досліджень та академічного плагіату) до дисциплінарної відповідальності $[13,14]$. Положення про первинну експертизу наукових праць на наявність академічного плагіату в Львівському національному медичному університеті імені Данила Галицького визначає основні поняття, завдання, принципи функціонування i призначення, склад i 
структуру та регламентує основні засади організації первинної автоматичної перевірки наукових праць - наукових текстів та дисертаційних матеріалів [3, 12, 16, 17]. Антиплагіатна експертиза є складовою системи внутрішнього університетського забезпечення якості освітньої діяльності та якості вищої освіти, “візитною” карткою академічної доброчесності [7]. Становлення у молоді поваги до інтелектуальної власності та авторських прав, до свободи та гідності людини, демократичних цінностей у їі індивідуальності $\epsilon$ важливою гуманітарною складовою здійснення успішних реформ у науководослідницькому процесі.

Мета статті. Удосконалення заходів протидії порущенням академічної доброчесності та академічному плагіату на основі аналізу чинного законодавства та положень Львівського національного медичного університету імені Данила Галицького, досвіду антиплагіатної експертизи.

Виклад основного матеріалу. ЗВО, як своєрідна модель колективного співіснування, $є$ періодом становлення і формування цінностей, установок $\mathrm{i}$ моделі поведінки, котрі визначатимуть місце молодої людини у дорослому житті [12-19]. Кодекс академічної етики Львівського національного медичного університету імені Данила Галицького визначає основні поняття, завдання академічної доброчесності, регламентує основні засади організації та контролю. У розділах Кодексу враховано вимоги базових документів (зі змінами та доповненнями): Законів України «Про освіту», «Про вищу освіту», «Про наукову і науково-технічну діяльність», «Про авторське право і суміжні права», на основі рекомендацій Асоціації Свропейських університетів щодо відкритого доступу до наукової інформації (2008 р.), міжнародних асоціацій IFLA, SPARC, LIBER, EiFL та ін [4-6]. Відповідно до ст. 7 Закону суб'єктами авторського права є автори творів, їх спадкоємці та особи, яким автори чи їх спадкоємці передали свої авторські майнові права.

Ознайомлення науково-педагогічних, наукових та інших працівників, а також студентів 3ВО 3 документами, що унормовують запобігання академічного плагіату та встановлюють відповідальність за академічний плагіат здійснюються шляхом формування, видання та розповсюдження методичних матеріалів із зазначенням вимог щодо належного оформлення посилань на використані у наукових і навчальних працях дані літератури та введення до освітніх програм i навчальних планів підготовки фахівців з вищою освітою навчальних дисциплін [12-18], що забезпечують формування загальних компетентностей з дотримування етичних норм і принципів, коректного менеджменту інформації [3-7, 13-17] при роботі 3 первинними та вторинними інформаційними ресурсами та об'єктами інтелектуальної власності; розміщення на веб-сайтах структурних підрозділів ЗВО правил академічної доброчесності щодо виконання наукових досліджень, рецензування статей та їх публікації [7, 8, 9]. Зі свого боку, особи, які навчаються у закладах вищої освіти зобов'язані виконувати вимоги освітньої (наукової) програми (індивідуального навчального плану (за наявності), дотримуючись академічної доброчесності, та досягати визначених для відповідного рівня вищої 
освіти результатів навчання (пункт 3 статі 63 Закону України «Про вищу освіту»). Запропонована навчальна дисципліна для здобувачів «Академічна доброчесність і антиплагіат», яка $є$ інтегрована у складову дисципліни «Універсальні навички дослідника» та спрямована на здобуття аналітичних компетентностей, необхідних під час планування і виконання дисертаційного дослідження, набуття навичок soft skills (гнучких навичок) для забезпечення адекватної комунікації наукової спільноти [16, 17]. Предметом вивчення $\epsilon$ аналіз чинного законодавства, можливостей технічних засобів, медико-біологічних, клінічних, соціальноекономічних та екологічних даних у контексті формування та порівняння гіпотез, теорій та отриманих результатів 3 науковим доробком інших дослідників i наукових шкіл, здійснення фахового аналізу інформації щодо можливого виникнення етичних порушень та конфліктів інтересів в контексті забезпечення етики досліджень, організації та проведення навчального процесу, наукової та професійної діяльності [8-13] для набуття практичних навичок, вмінь та компетенцій щодо протидії проявам академічної недоброчесності, фальсифікаціям і плагіату $[10,15]$. Окремі курси академічного письма для студентів та аспірантів є сьогодні радше винятком, ніж правилом [16-19].

Функціонування антиплагіатної експертизи у Львівському національному медичному університеті імені Данила Галицького відповідає сучасним нормам, інструкціям та вимогам щодо забезпечення академічної доброчесності $[16,17]$. Перевірка наукових робіт здійснюється адекватним програмним забезпеченням (ПЗ) в мережі Інтернет, локальних мережах та репозитарії ЗВО $[18,19]$. Репозитарій Львівського національного медичного університету імені Данила Галицького - це інституційний репозитарій відкритого доступу, що акумулює електронні повнотекстові документи наукового та навчально-методичного призначення, створені працівниками будь-якого структурного підрозділу ЛНМУ, аспірантами, магістрантами чи студентами університету, а також надає до них безкоштовний постійний доступ через Інтернет [10-15].

Сервіси для перевірки текстів на унікальність переважно працюють за подібними алгоритмами. Кожне антиплагіатне програмне забезпечення, незважаючи на подібність алгоритмів, має свої особливості, переваги та недоліки, особливості пошукової індексації, нюанси щодо зручності та доступності для практичного використання. При проведенні первинної антиплагіатної експертизи документ попередньо трансформується у формат .txt i перевіряється $[16,17,19]$. Пошук в Інтернеті здійснюється декількома пошуковими системами; візуалізується відсоток оригінальності тексту та список сайтів з відсотком збігу у відповідному кольорі в залежності від застосованих пошукових серверів $[11,12]$. При виборі програмного забезпечення необхідно звертати увагу на адекватність індексації, здатність повноцінно підтримували українську, російську та англійську мови, зручність та доступність для використання. Попередне (первинне) виявлення плагіату в наукових, навчальних, науково-методичних працях, дисертаційних та кваліфікаційних роботах здійснюється шляхом експертної оцінки (рецензування, відгуки керівників), використання 
комп'ютерних програм та вільнодоступних інтернет-ресурсів. Для технічної підтримки перевірки наукових та навчальних праць на наявність академічного плагіату в методичних вказівках ЗВО розміщується посилання на сервіси 3 первинної перевірки наукових праць на наявність плагіату [3-7, 11-15]. Науковий керівник (науковий консультант) роботи, завідувач кафедри має право здійснити попередній автоматизований аналіз роботи, звернувшись із електронною версією до відповідальної особи, довідка при цьому не надається.

Встановлення загального відсотку унікальності текстів здійснюється із застосування П3 “Unichek”, “Plagiarism Detector Pro v. 1092”, “Viper”. Для проведення первинної перевірки дисертаційних робіт щодо виявлення академічного плагіату застосовується алгоритмічна логічна функціональна послідовність антиплагітної експертизи дисертацій та авторефератів 3 проведенням аналізу відсотку унікальності тексту методом шингла 3 оптимізованими налаштуваннями параметрів глибокого пошуку та глибокою перевіркою П3 “Unichek", "Plagiarism Detector Pro v. 1092” тощо [19]. Перевірка статей у фахові журнали та тез доповідей здійснюється за допомогою ПЗ "Plagiarism Detector Pro v. 1092.", "Viper", “AntiPlagiarism.NET", "AdvegoPlagiatus" 3 урахуванням методичних рекомендацій МОН України, технічних аспектів оптимізації затрат часу та обсягу представленого на експертизу матеріалу. Окрім того проводиться перехресна (пороздільна) первинна перевірка розділів дисертаційних робіт та авторефератів дисертацій вільнодоступним П3 “AdvegoPlagiatus" та ліцензованим "AntiPlagiarism.NET”.

Загалом за трьохрічний період (2018-2020 pp) у Львівському національному медичному університеті імені Данила Галицького здійснено 5535 перевірок на наявність академічного плагіату у наукових та навчально-методичних працях. Порушення академічної доброчесності до моменту затвердження до публікації констатовано у 611 роботах (11,04 \% загальної вибірки), що було підставою до їх відхилення. За 2018 рік ПЗ “Advego Plagiatus", “AntiPlagiarism.NET", "ЕTXT Антиплагіат” перевірено 2350 наукових праць, відхилено та скеровано на доопрацювання 230 робіт (9,79 \% річної субвибірки). За 2019 рік ПЗ “Advego Plagiatus", "Viper", "AntiPlagiarism.NET" та інтернет ресурсом https://be1.ru/antiplagiat-online/ здійснено перевірку 2200 наукових та навчальнометодичних праць. Відхилено 286 робіт (13\% річної субвибірки). За 2020 р. П3 "Unichek", "Plagiarism Detector Pro", "Advego Plagiatus", "Viper", "AntiPlagiarism.NET" проведено перевірку та перехресну експертизу 985 наукових публікацій. Відхилено та скеровано на доопрацювання 95 робіт (9,64 \% річної субвибірки).

Комісія 3 питань етики та академічної доброчесності у Львівському національному медичному університеті імені Данила Галицького визначає процедуру розгляду справ щодо порушення Кодексу академічної етики та норм академічної доброчесності членами університетської спільноти, а також способи дисциплінарного впливу [16,17]. Члени комісії працюють на громадських засадах. Склад комісії затверджується наказом ректора. До складу комісії 
входять: проректор з наукової роботи; відповідальний за антикорупцію в 3ВО; вчений секретар разових спеціалізованих вчених рад (відповідальний за діяльність разових спеціалізованих вчених рад з присудження ступеня доктора філософіi); відповідальний за первинну технічну антиплагіатну перевірку наукових, навчально-методичних праць і дисертаційних матеріалів; секретар комісії 3 питань етики наукових досліджень, експериментальних розробок $\mathrm{i}$ наукових творів; відповідальні за планові наукові теми; науковий керівник Товариства молодих вчених; голова Комісії із забезпечення гендерної рівності та протидії дискримінації; завідувач відділом науково-медичної інформації та інтелектуальної власності; юрист-консультант (керівник юридичного відділу 3ВО). До роботи комісії без права участі в голосуванні можуть бути залучені внутрішні чи зовнішні експерти 3 питань, що розглядаються, представник деканату (декан або заступник декана) особи, справу якої розглядається на засіданні. Члени комісії не можуть делегувати свої повноваження іншим особам [6, 15-17].

Уніфікація контролю якості, діяльність комісії з питань етики та академічної доброчесності, впровадження навчальної дисципліни «Академічна доброчесність i антиплагіат» для підготовки фахівців - докторів філософіï (PhD), адекватна антиплагіатна експертиза стимулюють зростання цінності наукових досягнень, соціальну та професійну мобільність науково-педагогічних працівників, пошук нових партнерів для фінансування вищої освіти, посилення диверсифікації вищої освіти, нову структуру та постійне зростання цінності наукового знання та професійного досвіду [15, 17-19]. Виявлення факту академічної недоброчесності у наукових роботах можливе на етапі рецензування та / або представлення вченому секретареві, в редакцію або для розгляду на вченій раді з метою рекомендації до друку - для наукових робіт (монографія, підручник, навчальний посібник, стаття, тези, препринт тощо); на етапі розгляду на засіданні кафедри творів викладачів, що вимагають ухвалення кафедри; на етапі подання на перевірку кваліфікаційних робіт $[3,9-11,15]$. Якщо науковець не погоджується 3 результатами автоматизованої перевірки на плагіат, йому надається можливість викласти свою позицію та науково иï обгрунтувати у вигляді апеляції. Відповідальність за достовірність інформації про дотримання вимог академічної доброчесності здобувачем, яка подається до Вченої ради Університету щодо атестації здобувачів, покладається на проректора 3 наукової роботи, відповідальної особи за забезпечення діяльності спеціалізованих вчених рад 3 присудження ступенів доктора філософії та співробітника наукового відділу, відповідального за первинну автоматичну перевірку наукових текстів та дисертаційних матеріалів. У разі подання недостовірної інформації процедура атестації здобувача призупиняється. Повторне подання документів допускається не швидше, ніж через шість місяців. Експертна оцінка наукових праць, включаючи антиплагіатну перевірку, на нашу думку є важливою передумовою адекватності реалізації комплексних наукових тем та об'єктивізує загальну оцінку якості представлення результатів досліджень у фахових та інших наукових 
виданнях, включаючи зокрема дисертаційні роботи, монографії, навчальнометодичні посібники, статті та тези доповідей.

Висновки. Сучасними напрямками боротьби 3 академічним плагіатом $\epsilon$ програмна перевірка, оптимізація експертизи шляхом впровадження нових алгоритмів, застосування онлайн- i десктопного програмного забезпечення 3 позиції реалізації стратегій академічної доброчесності. Складова наукової комунікації та академічної доброчесності виявляється у антиплагіатній експертизі, яка об’єктивізує загальну оцінку якості та представлення результатів дослідження у дисертаційних роботах, фахових та інших наукових виданнях. Експертна оцінка наукових праць, включаючи антиплагіатні заходи, на нашу думку є важливою передумовою адекватності реалізації комплексних наукових тем на засадах академічної доброчесності, що грунтуються на повазі до колегнауковці, посідає важливе місце у сучасному науковому та освітньому процесі. Програмне забезпечення "Unichek", "Plagiarism Detector Pro", “Advego Plagiatus", "Viper", “AntiPlagiarism.NET" відповідає основним вимогам щодо програмної перевірки наукових праць з урахуванням технічних аспектів оптимізації затрат часу та обсягу представленого на експертизу матеріалу. Антиплагіатне забезпечення, що встановлене i функціонує у Львівському національному медичному університеті імені Данила Галицького відповідає сучасним критеріям та $є$ адекватним щодо проведення перевірки кириличних та латинськоабеткових наукових текстів.

\section{Лimepamypa:}

1. А. Григоренко, Збирання доказової бази при порушенні права інтелектуальної власності в мережі Інтернет, Інтелектуальна власність, № 7, с. 10-12, 2012.

2. Li Y. Text-based plagiarism in scientific writing: what Chinese supervisors think about copying and how to reduce it in stu-dents' writing / Y. Li // Sci. Eng. Ethics. - 2013. - Vol. 19 (2). - P.569-583.

3. Хобзей М. К. Деякі аспекти первинної експертизи наукових праць на наявність академічного плагіату / М. К. Хобзей, А. Р. Вергун // Медична освіта. - 2016. - № 3 (71). - С. 102-105.

4. Верховна Рада України. Законодавство України про охорону інтелектуальної власності, наказ, (2007, черв. 25), Про авторське право і суміжні права. [Електронний ресурс]. Доступно: https://zakon.rada.gov.ua/laws/show/3792-12\#Text

5. Закон України «Про вищу освіту» від 1 липня 2014 року № 1556-VII. - URL: http://osvita.ua/legislation/law/2235

6. Лист Міністерства освіти і науки України від 23.10.2018 р. № 1/9-650 «Керівникам закладів вищої освіти щодо рекомендацій з академічної доброчесності для закладів вищої освіти». - URL: https://zakononline.com.ua/documents/show/124272 124272.

7. Академічна чесність як основа сталого розвитку університету / Міжнародний благодійний Фонд «Міжнародний фонд дослідження освітньої політики»; за заг. ред. Т. В. Фінікова, А. Є. Артюхова. - К.: Таксон, 2016. - 234 с

8. Всесвітня конвенція про авторське право 1952 року, Київ: Концерн “Видавничій Дім IнЮре", 2004, 672 с.

9. Andreescu L. Self-plagiarism in academic publishing: the anatomy of a misnomer / L. Andreescu // Sci. Eng. Ethics. - 2013. - Vol. 19 (3). - P. 775-797.

10. Plagiarism in medical scientific research / R. A. A. Mohammed, O. M. Shaaban, D. G. Mahran [et al.] // J. Taibah University Med. Sci. - 2015. - Vol. 10 (1). - P. 6-11. 
11. Ю. Капіца, О. Рассомахіна, К. Шахбазян. Спеціальні механізми захисту авторського права і суміжних прав в Інтернеті, Інтелектуальна власність, № 4, с. 13-24, 2012.

12. Чоп'як В. В. Технічна експертиза наукових праць на наявність академічного плагіату / В.В. Чоп’як, О. Б. Надрага, А. Р. Вергун. - Львів: Вид-во ЛНМУ ім. Данила Галицького, 2016. - 49с.

13. А. Ковальова, Проблеми академічного плагіату та авторського права, Спеціальні історичні дисципліни, № 21, с. 61-71, 2014.

14. Шишка Р. Б. Плагіат та його прояви і небезпеки / Р. Б. Шишка // Часопис Київського університету права. - 2014. - № 4. - С. 170-176.

15. Хоружий Г. Ф. Європейська політика вищої освіти: монографія / Г. Ф. Хоружий. Полтава: Дивосвіт, 2016. - 384c.

16. Кодекс академічної етики Львівського національного медичного університету імені Данила Галицького. - 2020. - URL: http://nauka.meduniv.lviv.ua/wp-content/uploads/2020/04/ kodeks-akademichnoyi-etiki.pdf.

17. Положення про первинну експертизу наукових праць на наявність академічного плагіату в Львівському національному медичному університеті і мені Данила Галицького. 2020. - URL: http://nauka.meduniv.lviv.ua/wp-content/uploads/2020/03/nove_polozhennya_pro_ ekspertizu_2020.pdf.

18. Medical student plagiarism in problem-based learning courses / K.-J. Kim, J.-Y. Hwang, D.-W. Lee, M.-S. Shim // Medical Education Online. - 2016. - Vol. 21 (1). - P. 30537.

19. Вергун А. Р. Програмне забезпечення для перевірки наукових текстів на плагіат: інформаційний огляд / А. Р. Вергун, Л. В. Савенкова, С. О. Чуканова. - К., 2016. - 37 с.

\section{References:}

1. Grigorenko, A. (2012). Zbyrannia dokazovoi bazy pry porushenni prava intelektualnoi vlasnosti $\mathrm{v}$ merezhi Internet [Collection of evidence in violation of intellectual property rights on the Internet]. Intelektualna vlasnist - Intellectual Property, 7, 10-12. (in Ukrainian).

2. Li, Y. (2013).Text-based plagiarism in scientific writing: what Chinese supervisors think about copying and how to reduce it in students 'writing, Sci. Eng. Ethics, 19 (2), 569-583. (in English).

3. M. K. Khobzei, \& A.R. Vergun, (2016). Deiaki aspekty pervynnoi ekspertyzy naukovykh prats na naiavnist akademichnoho plahiatu [Some aspects of the initial examination of scientific papers for the presence of academic plagiarism]. Medychna osvita - Medical Education, 3 (71), 102105. (in Ukrainian).

4. Verkhovna Rada Ukrainy. Zakonodavstvo Ukrainy pro okhoronu intelektualnoi vlasnosti, nakaz, (2007, cherv. 25), Pro avtorske parvo I sumizhni prava [Legislation of Ukraine on the protection of intellectual property, order (2007, June 25), About copyright and related rights] (n.d.). zakon.rada.gov.ua. Retrieved from https://zakon.rada.gov.ua/laws/show/3792-12\#Text. (in Ukrainian).

5. (2014). Zakon Ukrainy «Pro vyshchu osvitu» 1 lypnia 2014 roku № 1556-VII [Law of Ukraine “On Higher Education” July 1, 2014 No. 1556-VII]. Retrieved from: http://osvita.ua/legislation/law/2235 [in Ukrainian].

6. Lyst Ministerstva osvity i nauky Ukrainy vid 23.10.2018 № 1/9-650 «Kerivnykam zakladiv vyshchoi osvity shchodo rekomendatsii $\mathrm{z}$ akademichnoi dobrochesnosti dlia zakladiv vyshchoi osvity» [Letter of the Ministry of Education and Science of Ukraine dated 23.10.2018 № 1 / 9-650 "To the heads of higher education institutions on recommendations on academic integrity for higher education institutions"]. Retrieved from: https://zakononline.com.ua/documents/show/124272_124272 [in Ukrainian].

7. Finikova, T.V., \& Artyukhova, A.Ye. (Eds.) (2016). Akademichna chesnist yak osnova staloho rozvytku universytetu [Academic honesty as a basis for sustainable develop ment of the university]. Mizhnarodnyi blahodiinyi Fond "Mizhnarodnyi fond doslidzhennia osvitnioi polityky" International Charitable Foundation "International Fund for Educational Policy Research". Kyiv: Takson [in Ukrainian]. 
8. Vsesvitnia konvenciia pro avtorske parvo 1952 roku (2004) [World Copyright Convention 1952]. Kyiv: Koncern "Vydavnychyi Dim inIure (in Ukrainian).

9. Andreescu, L. (2013). Self-plagiarism in academic publishing: the anatomy of a misnomer. Sci. Eng. Ethics., 19 (3), 775-797 (in English).

10. Mohammed, R.A.A., Shaaban, O.M., Mahran, D.G., Attellawy, H.N., Makhlof, A., \& Albasri, A. (2015). Plagiarism in medical scientific research. J. Taibah University Med. Sci., 10 (1), 6-11. (in English).

11. Kapitsa, Yu., Rassomakhina, O., Shahbazyan, K. (2012) Specialni mekhanizmy zakhystu avtorskoho prava I sumizhnykh prav v Interneti [Special mechanisms for the protection of copyright and related rights on the Internet]. Intelektualna vlasnist- Intellectual Property, 4, 13-24. (in Ukrainian).

12. Chopiak, V.V., Nadraha, O.B., \& Verhun, A.R. (2016). Tekhnichna ekspertyza naukovykh prats na naiavnist akademichnoho plahiatu [Technical examination of scientific works on the presence of academic plagiarism]. Lviv: Vyd-vo LNMU im. Danyla Halytskoho. [in Ukrainian]

13. Kovalova, A. (2014). Problemy akademichnoho plahiatu ta avtorskoho prava [Problems of academic plagiarism and copyright]. Spetsialni istorychni dystsypliny - Special historical disciplines, 21, 61-71. (in Ukrainian).

14. Shyshka, R.B. (2014). Plahiat ta yoho proiavy I nebezpeky [Plagiarism and its manifestations and dangers]. Chasopys Kyivskoho universytetu prava - Journal of Kyiv University of Law, 4, 170-176 [in Ukrainian].

15. Khoruzhyy, H.F. (2016). Yevropeiska polityka vyshchoi osvity. Monohraphia [Khoruzhiy GF European policy of higher education. Monograph]. Poltava: Dyvosvit [in Ukrainian].

16. (2019). Kodeks akademichnoi etyky Lvivskoho natsionalnoho medychnoho universytetu imeni Danyla Halytskoho [Code of Academic Ethics of Danylo Halytskyi Lviv National Medical University]. Retrieved from: http://nauka.meduniv.lviv.ua/wpcontent/uploads/2020/04/kodeksakademichnoyietiki.pdf [in Ukrainian].

17. (2020). Polozhennia pro pervynnu ekspertyzu naukovykh prats na naiavnis akademichnoho plahiatu v Lvivskomu natsionalnomu medychnomu universyteti imeni Danyla Halytskoho [Regulations on the initial examination of scientific papers for the presence of academic plagiarism at the Lviv National Medical University named after Danylo Halytskyi]. Retrieved from: http://nauka.meduniv.lviv.ua/wpcontent/uploads/2020/03/nove_polozhennya_pro_ekspertizu_2020.pdf [in Ukrainian].Kyong-Jee Kim, Jee Young Hwang, Dong-Wook Lee \& Min-Sung Shim, Medical student plagiarism in problem-based learning courses, Medical Education Online, 21: 1, 2016, pp. 305-337. (in English).

18. Kim, K.-J., Hwang, J.-Y., Lee, D.-W., \& Shim, M.-S. (2016). Medical student plagiarism in problem-based learning courses. Medical Education Online, 21 (1), 30537. (in English).

19. Vergun, A.R., Savenkova, L.V., \& Chukanova, S.O. (2016). Prohramne zabezpechennia dlia perevirky naukovykh tekstiv na plahiat. Informatsiynyy ohliad [Software for checking some scientific texts on plagiarism. Information review]. Kyiv [in Ukrainian]. 